\title{
The effect of baseline physical activity on cardiovascular outcomes and new-onset diabetes in patients treated for hypertension and left ventricular hypertrophy: the LIFE study
}

\author{
- E. Fossum ${ }^{1}$, G. W. Gleim², S. E. Kjeldsen ${ }^{1,3}$, J. R. Kizer ${ }^{4}$, S. Julius ${ }^{3}$, R. B. Devereux , W. E. Brady ${ }^{2}$, D. A. Hille ${ }^{2}$, \\ P. A. Lyle ${ }^{2}$ \& B. Dahlöf \\ From the ${ }^{I}$ Ullevaal University Hospital, University of Oslo, Oslo, Norway; ${ }^{2}$ Merck Research Laboratories, West Point, PA; \\ ${ }^{3}$ University of Michigan, Ann Arbor, MI; ${ }^{4}$ Weill Medical College of Cornell University, New York, NY, USA, and ${ }^{5}$ Sahlgrenska \\ University Hospital/Östra, Göteborg, Sweden
}

\begin{abstract}
Fossum E, Gleim GW, Kjeldsen SE, Kizer JR, Julius S, Devereux RB, Brady WE, Hille DA, Lyle PA, Dahlöf B (University of Oslo, Oslo, Norway, Merck Research Laboratories, West Point, PA; University of Michigan, Ann Arbor, MI, Cornell University, New York, NY, USA; and University Hospital/Östra, Göteborg, Sweden). The effect of baseline physical activity on cardiovascular outcomes and new-onset diabetes in patients treated for hypertension and left ventricular hypertrophy: the LIFE study. J Intern Med 2007; 262: 439-448.
\end{abstract}

Objectives. Physical activity (PA) is a preventive strategy for cardiovascular disease and for managing cardiovascular risk factors. There is little information on the effectiveness of PA for the prevention of cardiovascular outcomes once cardiovascular disease is present. Thus, we studied the relationship between PA at baseline and cardiovascular events in a high-risk population.

Design. A prespecified analyses of observational data in a prospective, randomized hypertension study.

Setting. Losartan Intervention For Endpoint reduction in hypertension (LIFE) study

Subjects. Hypertension and left ventricular hypertrophy $(\mathrm{LVH})(n=9193)$.
Interventions. Losartan versus atenolol.

Main outcome measures. Reported level of PA: never exercise, exercise $\leq 30 \mathrm{~min}$ twice per week, or exercise $>30$ min twice per week at baseline and after a mean of 4.8 years of treatment with losartan- versus atenolol-based therapy. Risk reductions were calculated by level of PA for the primary composite endpoint and its components cardiovascular death, stroke and myocardial infarction, and also all-cause mortality and new-onset diabetes.

Results. A modest level of PA ( $>30$ min twice per week) was associated with significant reductions in risk for the primary composite end-point [adjusted hazard ratio (aHR) $0.70, P<0.001$ ) and its components, all-cause mortality (aHR 0.65, $P<0.001$ ), and new-onset diabetes (aHR 0.66, $P<0.001$ ).

Conclusion. A modest level of self-reported PA ( $>30$ min twice per week) in patients with hypertension and LVH in the LIFE study was associated with significant reductions in risk for the primary composite end-point and its components of cardiovascular death, stroke, and myocardial infarction, all-cause mortality, and new-onset diabetes.

Keywords: atenolol, cardiovascular risk, exercise, LIFE study, losartan, physical activity, type 2 diabetes. 


\section{Introduction}

The 1.5- to 2.4-fold increase in relative risk for coronary heart disease associated with physical inactivity is comparable to the risks associated with hypercholesterolaemia, hypertension or smoking [1]. The estimated costs of diseases associated with physical inactivity in the United States are $\$ 76$ billion annually [2]. Physical activity (PA) is an accepted preventive approach for cardiovascular disease and for managing selected cardiovascular risk factors [3]. In previous studies, groups with the lowest levels of PA, assessed by various methods, were at greatest risk for cardiovascular disease [4-16]. However, once cardiovascular disease is present, there is little information on the effectiveness of PA for the prevention of cardiovascular outcomes. To our knowledge, there are no data in the literature from patients with hypertensive left ventricular hypertrophy (LVH) that relate PA to cardiovascular morbidity/mortality. The Losartan Intervention For Endpoint reduction in hypertension (LIFE) study provided one of the first opportunities to study the relationships between PA at baseline and cardiovascular outcomes and new-onset diabetes in a large, well-conducted endpoint trial that enrolled patients with significant cardiovascular pathology.

\section{Methods}

The LIFE study was a prospective, multinational, double-blind, randomized clinical trial that examined the effects of losartan- compared with atenolol-based antihypertensive treatment in 9193 patients with hypertension and electrocardiographic (ECG) LVH. The study design, patient characteristics and results have been published [17-19]. In short, patients aged 55-80 years with ECG-LVH and with trough diastolic blood pressure $95-115 \mathrm{mmHg}$ and/or systolic blood pressure $160-200 \mathrm{mmHg}$ after 2 weeks of placebo treatment were eligible for participation in the study. Patients with medical conditions requiring specific treatment with an angiotensin-converting enzyme inhibitor, angiotensin receptor blocker or beta-blocker were excluded from the study, as were patients with history of stroke or myocardial infarction within 6 months prior to the start of the study or with left ventricular ejection fraction of
$40 \%$ or less. Eligible patients $(n=9193)$ were randomized to losartan or atenolol and matching placebo. The titration scheme was as follows: step 1, study drug $50 \mathrm{mg}$; step 2, study drug $50 \mathrm{mg}$ plus hydrochlorothiazide (HCTZ) $12.5 \mathrm{mg}$; step 3, study drug $100 \mathrm{mg}$ plus HCTZ $12.5 \mathrm{mg}$; step 4, study drug $100 \mathrm{mg}$ plus HCTZ $\geq 25 \mathrm{mg}$ or addition of other antihypertensive agents (excluding angiotensin-converting enzyme inhibitors, angiotensin receptor blockers or beta-blockers). Target blood pressure was less than 140/90 mmHg. Patients were included between June 1995 and April 1997 and followed for a mean of 4.8 years.

The primary end-point was a composite of cardiovascular death, nonfatal and fatal stroke, and nonfatal and fatal myocardial infarction. All end-points were adjudicated by an expert end-point classification committee. New-onset diabetes was assessed using WHO criteria [20] in the 7998 patients who did not have diabetes at baseline [21]. Quality of life was assessed using a visual analogue scale on which patients responded to the following prompt: 'Below is a scale from 0 to 100 . On this scale, 100 is equivalent to the best imaginable health state and 0 is the worst imaginable health state. Please mark with an $\mathrm{X}$ where on the scale you would place your present health state'.

Patients reported their level of PA at baseline and at the end of follow-up as (i) never exercise, (ii) exercise $\leq 30 \mathrm{~min}$ twice per week or (iii) exercise $>30 \mathrm{~min}$ twice per week. Patients were instructed to select one of these categories that best described their exercise habits. Mild (e.g. walking) or more strenuous exercise was applicable. In the present analyses, data were stratified according to these three groups of exercise level.

All patients provided written informed consent, and the protocol was approved by all relevant ethical review committees.

Data management and analysis were performed using SAS version 8 (Cary, NC, USA) software. Events were analysed using the intent-to-treat approach. Hazard ratios (HRs) for outcomes were assessed using Cox regression analysis with and without 
adjustment for baseline current smoking (yes/no), alcohol intake (yes/no), gender, age and race (white, black and other), degree of LVH by Cornell voltageduration product and Sokolow-Lyon criteria (measured as continuous variables), and the Framingham risk score [age, gender, total and high-density lipoprotein (HDL) cholesterol, systolic blood pressure, smoking, diabetes and LVH] [22]. The never-exercise group was assigned an HR of 1. Kaplan-Meier curves were generated for the primary composite end-point and its components and depict unadjusted rates. All tests were performed at two-sided 5\% significance levels.

\section{Results}

Of the 9185 patients with PA data available at baseline, $51.8 \%$ exercised $>30 \mathrm{~min}$ twice per week, whilst $26.2 \%$ exercised $\leq 30$ min twice per week and $22.0 \%$ never exercised (Table 1). The baseline characteristics amongst the PA groups are shown in Table 1. There were significantly higher proportions of women, smokers, obese patients, and patients with diabetes and signs of reduced renal function at lower PA levels. Moreover, patients who did not exercise had a history of significantly more cardiovascular disease. There were significant trends to higher quality-of-life score and lower heart rate with higher PA level (Table 1). The groups had comparable values for Framingham risk score. Levels of serum uric acid, sodium, potassium and urine creatinine, and number of subjects with a medical history of peripheral vascular disease, atrial fibrillation or isolated systolic hypertension (data not shown) did not differ amongst groups.

Study drug distribution (data not shown) was similar amongst the PA groups.

The reductions in blood pressure and heart rate were clinically similar amongst the PA groups (systolic blood pressure reduced $29-31 \mathrm{mmHg}$, diastolic blood pressure $16-17 \mathrm{mmHg}$ and heart rate 5 beats per minute). The concomitant use of aspirin (21\% in all groups) or statins $(5.8-6.9 \%)$ were not statistically different amongst the PA groups.
The unadjusted and adjusted HR (Table 2) and Kaplan-Meier curves (Fig. 1) illustrate that patients exercising >30 min twice per week experienced significantly lower rates of the primary composite end-point and its components of cardiovascular death, stroke and myocardial infarction $(P$ for myocardial infarction $=0.037$ unadjusted; $P=0.068$ adjusted) compared with those who never exercise. The risk for cardiovascular death $(P=0.017$ unadjusted; $P=0.062$ adjusted) and all-cause mortality $(P=0.013$ unadjusted; $P=0.085$ adjusted $)$ tended to be intermediate in the $\leq 30 \mathrm{~min}$ twice per week group compared with the never-exercise group. Risks for stroke and the primary composite end-point were not significantly different between the $\leq 30$ min twice per week and never-exercise groups in the unadjusted and adjusted analyses. By subtracting cardiovascular deaths from all-cause deaths, there was a modest but not significant $(P=0.28)$ trend towards fewer noncardiovascular deaths with higher levels of exercise. Analyses additionally adjusted for available baseline body mass index, serum creatinine, urinary albumin/ creatinine ratio and cardiovascular disease data (22.8$28.6 \%$ of the subjects as specified in Table 1) were consistent with those described above. A separate gender analyses (Table 2a,b) showed the same trend as described above with lower end-point rates amongst the physically active subjects. However, the absolute end-point rate per 1000 years of follow-up was clearly higher amongst the males compared with the females.

The risk of new-onset diabetes was decreased by $36 \%$ $(P<0.001)$ in the patients who exercised $>30 \mathrm{~min}$ twice per week compared with the patients who never exercised (Table 3), and was similar and consistent after additional adjustments for available baseline body mass index, serum creatinine, urinary albumin/ creatinine ratio and cardiovascular disease data. The risk reduction was not significantly different between the two treatment groups (data not shown). The risk reduction was not significant for the $\leq 30$ min twice per week compared with the never-exercise group. A separate gender analyses (Table 3a,b) showed a trend similar to that described above with higher absolute event rates amongst males compared with females. 
Table 1 Baseline characteristics by physical activity categories

\begin{tabular}{|c|c|c|c|c|}
\hline & $\begin{array}{l}\text { Never } \\
(n=2020)\end{array}$ & $\begin{array}{l}\leq 30 \text { min twice/week } \\
(n=2407)\end{array}$ & $\begin{array}{l}>30 \text { min twice/week } \\
(n=4758)\end{array}$ & $P$-value \\
\hline \multicolumn{5}{|l|}{ Characteristic } \\
\hline Age, years & $67.61(7.30)$ & $67.13(7.11)$ & $66.57(6.80)$ & $<0.001$ \\
\hline Female, $n(\%)$ & $1260(62.4)$ & $1350(56.1)$ & $2351(49.4)$ & $<0.001$ \\
\hline \multicolumn{5}{|l|}{ Race, $n(\%)$} \\
\hline White & $1737(86.0)$ & $2214(92.0)$ & $4546(95.5)$ & \multirow[t]{3}{*}{$<0.001$} \\
\hline Black & $222(11.0)$ & $147(6.1)$ & $162(3.4)$ & \\
\hline Other & $61(3.0)$ & $46(1.9)$ & $50(1.1)$ & \\
\hline \multicolumn{5}{|l|}{ Smoking status, $n(\%)$} \\
\hline Never & $975(48.3)$ & $1247(51.8)$ & $2432(51.1)$ & \multirow[t]{5}{*}{$<0.001$} \\
\hline Ex-smoker & $584(28.9)$ & 779 (32.4\%) & $1668(35.1)$ & \\
\hline $1-10 \mathrm{day}^{-1}$ & $249(12.3)$ & $222(9.2)$ & $409(8.6)$ & \\
\hline $11-20 \mathrm{day}^{-1}$ & $140(6.9)$ & $124(5.2)$ & $171(3.6)$ & \\
\hline$>20$ day $^{-1}$ & $70(3.5)$ & $35(1.5)$ & $77(1.6)$ & \\
\hline \multicolumn{5}{|l|}{ Alcohol intake } \\
\hline None & $1119(55.4)$ & $1101(45.7)$ & 1994 (41.9) & \multirow[t]{4}{*}{$<0.001$} \\
\hline $1-4$ week $^{-1}$ & $651(32.2)$ & $983(40.8)$ & 1965 (41.3) & \\
\hline $5-10$ week $^{-1}$ & $177(8.8)$ & $230(9.6)$ & $590(12.4)$ & \\
\hline$>10$ week $^{-1}$ & $73(3.6)$ & $93(3.9)$ & $205(4.3)$ & \\
\hline Quality of life & $70.75(18.33)$ & $73.82(17.34)$ & $77.63(15.96)$ & $<0.001$ \\
\hline Systolic blood pressure, $\mathrm{mmHg}$ & $175.79(14.41)$ & $173.96(14.10)$ & $174.07(14.31)$ & $<0.001$ \\
\hline Diastolic blood pressure, $\mathrm{mmHg}$ & $97.71(9.42)$ & $97.70(8.76)$ & $97.87(8.70)$ & 0.673 \\
\hline \multicolumn{5}{|l|}{ Category } \\
\hline Body mass index, $\mathrm{kg} \mathrm{m}^{-2}$ & $29.11(5.59)$ & $28.32(4.94)$ & $27.36(4.20)$ & $<0.001$ \\
\hline Heart rate, beats $\min ^{-1}$ & $76.05(11.62)$ & $74.26(10.81)$ & $72.63(10.87)$ & $<0.001$ \\
\hline Cornell product $\mathrm{mm} \times \mathrm{ms}$ & $2864(1007)$ & $2864(1068)$ & $2786(1024)$ & 0.001 \\
\hline Sokolow-Lyon, mm & $29.01(10.79)$ & $29.83(10.26)$ & $30.49(10.19)$ & $<0.001$ \\
\hline Framingham risk score & $22.58(9.36)$ & $22.49(9.53)$ & $22.26(9.40)$ & 0.357 \\
\hline \multicolumn{5}{|l|}{ Medical history, $n(\%)$} \\
\hline Cardiovascular disease & $578(28.6)$ & $644(26.8)$ & $1084(22.8)$ & $<0.001$ \\
\hline Coronary heart disease & $377(18.7)$ & $413(17.2)$ & $678(14.2)$ & $<0.001$ \\
\hline Cerebrovascular disease & $200(9.9)$ & $207(8.6)$ & $321(6.7)$ & $<0.001$ \\
\hline Heart failure & $59(2.9)$ & $58(2.4)$ & $49(1.0)$ & $<0.001$ \\
\hline Diabetes & $360(17.8)$ & $324(13.5)$ & $509(10.7)$ & $<0.001$ \\
\hline Chronic obstructive pulmonary disease & $118(5.8)$ & $105(4.4)$ & $161(3.4)$ & $<0.001$ \\
\hline Haemoglobin, $\mathrm{g} \mathrm{L}^{-1}$ & $140.90(12.91)$ & $142.60(12.44)$ & $142.98(11.43)$ & $<0.001$ \\
\hline Serum creatinine, $\mu \mathrm{mol} \mathrm{L}^{-1}$ & $89.36(22.41)$ & $87.21(21.30)$ & $85.76(18.45)$ & $<0.001$ \\
\hline ALAT, $\mu$ kat $\mathrm{L}^{-1}$ & $0.42(0.29)$ & $0.46(0.34)$ & $0.47(0.42)$ & $<0.001$ \\
\hline Serum glucose, $\mathrm{mmol} \mathrm{L}^{-1}$ & $6.27(2.52)$ & $6.10(2.20)$ & $5.88(2.02)$ & $<0.001$ \\
\hline
\end{tabular}


Table 1 (Continued)

\begin{tabular}{lcccr}
\hline & $\begin{array}{l}\text { Never } \\
(n=2020)\end{array}$ & $\begin{array}{l}\leq 30 \text { min twice/week } \\
(n=2407)\end{array}$ & $\begin{array}{l}>30 \text { min twice } / \text { week } \\
(n=4758)\end{array}$ & $P$-value \\
\hline Total cholesterol, mmol L & $6.01(1.15)$ & $6.05(1.11)$ & $6.05(1.12)$ & 0.425 \\
HDL cholesterol, mmol L $^{-1}$ & $1.47(0.43)$ & $1.47(0.43)$ & $1.52(0.44)$ & $<0.001$ \\
Urine albumin (median), mmol L & 15.00 & 12.00 & 9.00 & $<0.001$ \\
Urine albumin/creatinine (median), $\mathrm{mmol} \mathrm{g}^{-1}$ & 1.75 & 1.38 & 1.10 & $<0.001$
\end{tabular}

ALAT, alanine aminotransferase; HDL, high-density lipoprotein. Values are mean (SD) unless otherwise noted. Categorical variables were assessed with a chi-square test. Continuous variables were assessed with ANOVA, except for urine albumin and urine albumin/creatinine, which were assessed with a test of medians. Quality of life index was measured on a visual analogue scale from 0 to 100 , where 0 was the worst and 100 was the best quality of life.

Table 2 Cardiovascular end-points in physical activity categories: (a) females and (b) males

\begin{tabular}{|c|c|c|c|c|c|c|}
\hline & $\begin{array}{l}\text { Events/patients } \\
(\%)\end{array}$ & Rate & $\begin{array}{l}\text { Unadjusted HR } \\
(95 \% \mathrm{CI})\end{array}$ & $P$-value & $\begin{array}{l}\text { Adjusted HR } \\
(95 \% \mathrm{CI})\end{array}$ & $P$-value \\
\hline \multicolumn{7}{|l|}{ Category } \\
\hline \multicolumn{7}{|c|}{ Primary composite end-point } \\
\hline Never & $294 / 2020(14.6)$ & 32.5 & - & - & - & - \\
\hline$\leq 30 \mathrm{~min}$ twice/week & $330 / 2407(13.7)$ & 29.9 & $0.92(0.79-1.08)$ & 0.301 & $0.95(0.81-1.12)$ & 0.536 \\
\hline$>30 \mathrm{~min}$ twice/week & $472 / 4758(9.9)$ & 21.2 & $0.65(0.56-0.75)$ & $<0.001$ & $0.70(0.60-0.81)$ & $<0.001$ \\
\hline \multicolumn{7}{|l|}{ Cardiovascular death } \\
\hline Never & $147 / 2020(7.3)$ & 15.6 & - & - & - & - \\
\hline$\leq 30 \mathrm{~min}$ twice/week & $136 / 2407(5.7)$ & 11.8 & $0.75(0.60-0.95)$ & 0.017 & $0.80(0.63-1.01)$ & 0.062 \\
\hline$>30 \mathrm{~min}$ twice/week & $155 / 4758(3.3)$ & 6.7 & $0.43(0.34-0.54)$ & $<0.001$ & $0.49(0.39-0.62)$ & $<0.001$ \\
\hline \multicolumn{7}{|l|}{ Stroke } \\
\hline Never & $137 / 2020(6.8)$ & 15.1 & - & - & - & - \\
\hline$\leq 30 \mathrm{~min}$ twice/week & $167 / 2407(6.9)$ & 15.0 & $0.99(0.79-1.25)$ & 0.959 & $1.04(0.82-1.30)$ & 0.768 \\
\hline$>30 \mathrm{~min}$ twice/week & $237 / 4758(5.0)$ & 10.5 & $0.70(0.57-0.86)$ & 0.001 & $0.77(0.62-0.96)$ & 0.019 \\
\hline \multicolumn{7}{|l|}{ Myocardial infarction } \\
\hline Never & $93 / 2020(4.6)$ & 10.1 & - & - & - & - \\
\hline$\leq 30 \mathrm{~min}$ twice/week & $117 / 2407$ (4.9) & 10.4 & $1.02(0.78-1.34)$ & 0.878 & $1.03(0.79-1.36)$ & 0.812 \\
\hline$>30 \mathrm{~min}$ twice/week & $176 / 4758(3.7)$ & 7.8 & $0.77(0.60-0.98)$ & 0.037 & $0.79(0.61-1.02)$ & 0.068 \\
\hline \multicolumn{7}{|l|}{ All-cause mortality } \\
\hline Never & $241 / 2020(11.9)$ & 25.5 & - & - & - & - \\
\hline$\leq 30 \mathrm{~min}$ twice/week & $236 / 2407(9.8)$ & 20.4 & $0.80(0.67-0.95)$ & 0.013 & $0.85(0.71-1.02)$ & 0.085 \\
\hline$>30 \mathrm{~min}$ twice/week & $337 / 4758(7.1)$ & 14.6 & $0.57(0.48-0.67)$ & $<0.001$ & $0.65(0.55-0.77)$ & $<0.001$ \\
\hline \multicolumn{7}{|l|}{ (a) Females } \\
\hline \multicolumn{7}{|c|}{ Primary composite end-point } \\
\hline Never & $155 / 1260(12.3)$ & 26.9 & - & - & - & - \\
\hline$\leq 30 \mathrm{~min}$ twice/week & $153 / 1350(11.3)$ & 13.3 & $0.90(0.72-1.12)$ & 0.339 & $1.05(0.84-1.32)$ & 0.667 \\
\hline$>30 \mathrm{~min}$ twice/week & $168 / 2351(7.1)$ & 14.9 & $0.55(0.44-0.69)$ & $<0.001$ & $0.73(0.59-0.92)$ & 0.006 \\
\hline \multicolumn{7}{|l|}{ Cardiovascular death } \\
\hline Never & $70 / 1260(5.6)$ & 11.7 & - & - & - & - \\
\hline$\leq 30 \mathrm{~min}$ twice/week & $67 / 1350(5.0)$ & 10.2 & $0.87(0.62-1.22)$ & 0.416 & $1.029(0.73-1.44)$ & 0.871 \\
\hline
\end{tabular}


Table 2 (Continued)

\begin{tabular}{|c|c|c|c|c|c|c|}
\hline & $\begin{array}{l}\text { Events/patients } \\
(\%)\end{array}$ & Rate & $\begin{array}{l}\text { Unadjusted HR } \\
(95 \% \mathrm{CI})\end{array}$ & $P$-value & $\begin{array}{l}\text { Adjusted HR } \\
(95 \% \mathrm{CI})\end{array}$ & $P$-value \\
\hline$>30 \mathrm{~min}$ twice/week & $55 / 2351(2.3)$ & 4.8 & $0.41(0.28-0.58)$ & $<0.001$ & $0.55(0.38-0.79)$ & 0.001 \\
\hline \multicolumn{7}{|l|}{ Stroke } \\
\hline Never & $81 / 1260(6.4)$ & 15.1 & - & - & - & - \\
\hline$\leq 30 \mathrm{~min}$ twice/week & $85 / 1350(6.3)$ & 15.0 & $0.95(0.70-1.29)$ & 0.741 & $1.12(0.82-1.52)$ & 0.470 \\
\hline$>30 \mathrm{~min}$ twice/week & $97 / 2351(4.1)$ & 10.5 & $0.61(0.46-0.82)$ & 0.001 & $0.83(0.61-1.12)$ & 0.222 \\
\hline \multicolumn{7}{|l|}{ Myocardial infarction } \\
\hline Never & $48 / 1260(3.8)$ & 8.2 & - & - & - & - \\
\hline$\leq 30 \mathrm{~min}$ twice/week & $54 / 1350(4.0)$ & 8.4 & $1.02(0.69-1.51)$ & 0.920 & $1.16(0.78-1.71)$ & 0.467 \\
\hline$>30 \mathrm{~min}$ twice/week & $54 / 2351(2.3)$ & 4.7 & $0.58(0.39-0.85)$ & 0.0056 & $0.731(0.49-1.09)$ & 0.125 \\
\hline \multicolumn{7}{|l|}{ All-cause mortality } \\
\hline Never & $124 / 1260(9.8)$ & 20.7 & - & - & - & - \\
\hline$\leq 30 \mathrm{~min}$ twice/week & $111 / 1350(8.2)$ & 16.9 & $0.81(0.63-1.05)$ & 0.114 & $0.95(0.74-1.24)$ & 0.718 \\
\hline$>30 \mathrm{~min}$ twice/week & $131 / 2351(5.6)$ & 11.3 & $0.54(0.43-0.69)$ & $<0.001$ & $0.72(0.56-0.92)$ & 0.010 \\
\hline \multicolumn{7}{|l|}{ (b) Males } \\
\hline \multicolumn{7}{|c|}{ Primary composite end-point } \\
\hline Never & $139 / 760(18.3)$ & 42.3 & - & - & - & - \\
\hline$\leq 30 \mathrm{~min}$ twice/week & $177 / 1057(16.7)$ & 37.7 & $0.89(0.71-1.11)$ & 0.3141 & $0.90(0.72-1.13)$ & 0.377 \\
\hline$>30 \mathrm{~min}$ twice/week & $304 / 2407(12.6)$ & 27.6 & $0.65(0.54-0.80)$ & $<0.001$ & $0.71(0.58-0.87)$ & 0.001 \\
\hline \multicolumn{7}{|l|}{ Cardiovascular death } \\
\hline Never & $77 / 760(10.1)$ & 22.3 & - & - & - & - \\
\hline$\leq 30 \mathrm{~min}$ twice/week & 69/1057 (6.5) & 13.8 & $0.62(0.45-0.86)$ & 0.004 & $0.65(0.47-0.90)$ & 0.010 \\
\hline$>30 \mathrm{~min}$ twice/week & $100 / 2407(4.2)$ & 8.7 & $0.39(0.29-0.52)$ & $<.001$ & $0.45(0.33-0.61)$ & $<0.001$ \\
\hline \multicolumn{7}{|l|}{ Stroke } \\
\hline Never & $56 / 760(7.4)$ & 16.9 & - & - & - & - \\
\hline$\leq 30 \mathrm{~min}$ twice/week & $82 / 1057(7.8)$ & 17.2 & $1.02(0.73-1.43)$ & 0.906 & $0.99(0.70-1.39)$ & 0.942 \\
\hline$>30 \mathrm{~min}$ twice/week & $140 / 2407(5.8)$ & 12.5 & $0.74(0.54-1.01)$ & 0.059 & $0.76(0.56-1.05)$ & 0.094 \\
\hline \multicolumn{7}{|l|}{ Myocardial infarction } \\
\hline Never & $45 / 760(5.9)$ & 13.5 & - & - & - & - \\
\hline$\leq 30 \mathrm{~min}$ twice/week & $63 / 1057(6.0)$ & 13.0 & $0.97(0.66-1.42)$ & 0.857 & $0.99(0.68-1.46)$ & 0.973 \\
\hline$>30$ min twice/week & $122 / 2407(5.1)$ & 10.8 & $0.80(0.57-1.13)$ & 0.208 & $0.86(.61-1.23)$ & 0.413 \\
\hline \multicolumn{7}{|l|}{ All-cause mortality } \\
\hline Never & $117 / 760(15.4)$ & 33.9 & - & - & - & - \\
\hline$\leq 30 \mathrm{~min}$ twice/week & 125/1057 (11.8) & 25.0 & $0.74(0.57-0.95)$ & 0.018 & $0.77(0.60-1.00)$ & 0.049 \\
\hline$>30 \mathrm{~min}$ twice/week & 206/2407 (8.6) & 17.9 & $0.53(0.42-0.66)$ & $<0.001$ & $0.60(0.48-0.76)$ & $<0.001$ \\
\hline
\end{tabular}

CI, confidence interval; HR, hazard ratio. Rate is per 1000 years of patient follow-up. The never-exercise group was designated an HR of 1. Adjusted HRs are adjusted for baseline age, gender, current smoking (yes/no), alcohol use (yes/no), race (white, black, other), degree of left ventricular hypertrophy and Framingham risk score.

The distribution of patients amongst the PA categories at baseline and at the end of follow-up was similar in the losartan and atenolol treatment groups (data not shown). There were no interactions between treatment and exercise for the primary composite end-point or its components. The reported level of muscular side effects was low (data not shown) and not different between the two drugs. 
(a)

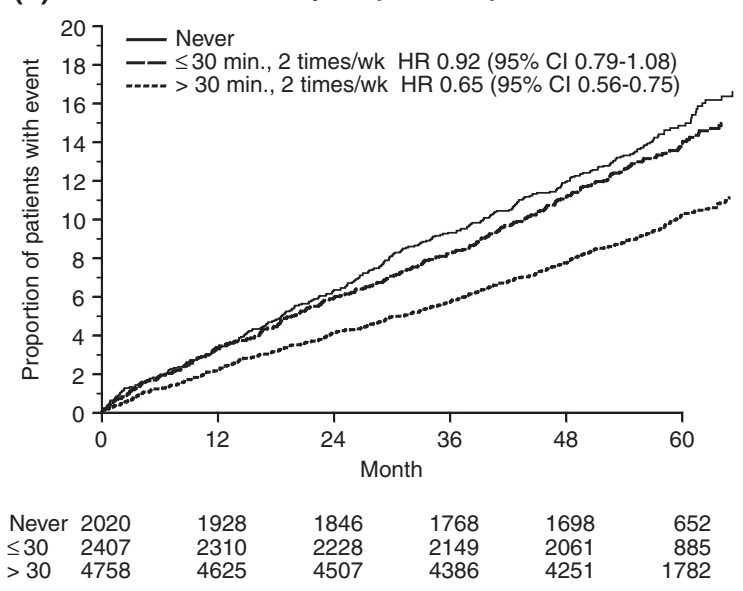

(c)

Stroke
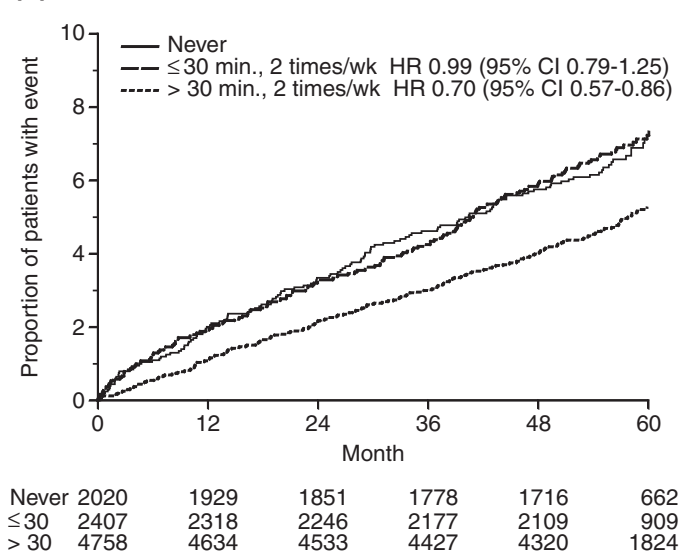

(b)

Cardiovascular death

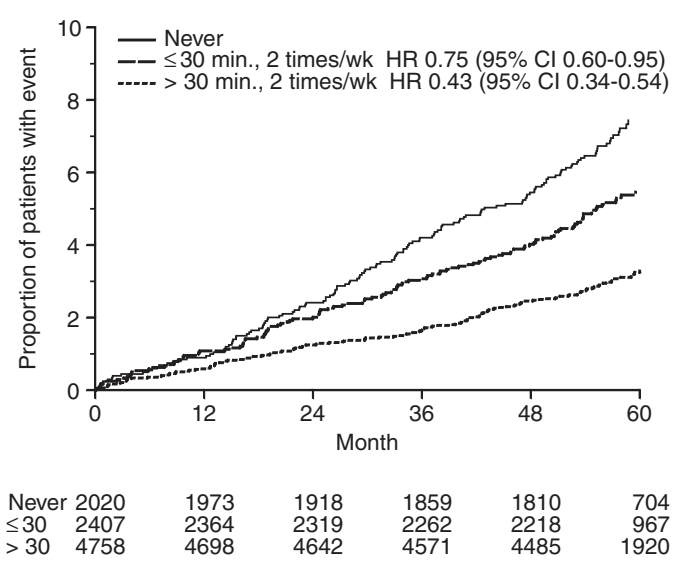

(d)

Myocardial infarction

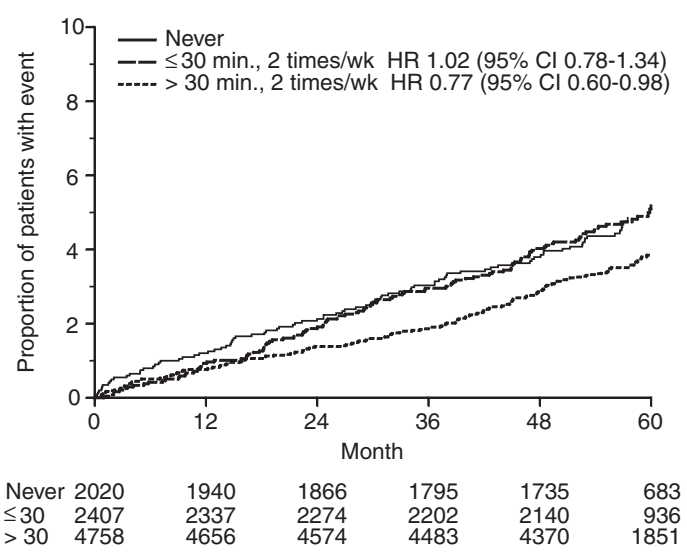

Fig. 1 Kaplan-Meier curves: (a) primary composite end-point; (b) cardiovascular death; (c) stroke; (d) myocardial infarction.

\section{Discussion}

Our data suggest that a modest level of PA $(>30 \mathrm{~min}$ twice per week) in patients with hypertension and LVH in the LIFE study was associated with significant reductions in risks for the primary composite end-point and its components of cardiovascular death, stroke, and myocardial infarction, and also all-cause mortality and new-onset diabetes.

Although it is accepted that PA reduces risks for cardiovascular events and new-onset diabetes, agreement about the level of PA (frequency, intensity, duration) has not been established because study results of the effects of PA for hypertension, coronary heart disease, stroke, and cardiovascular and allcause mortality have been inconsistent [4-9, 23-35]. An important finding in this study is the substantial benefit demonstrated with very modest PA. The American Heart Association [3] and the American College of Sports Medicine [23] recommend $30 \mathrm{~min}$ or more of moderate-intensity primarily aerobic PA on most (preferably all) days of the week for reducing the risk associated with hypertension. Although we do not know the median activity level in our PA categories, the level of PA that was found to 
Table 3 New-onset diabetes in physical activity categories: (a) females and (b) males

\begin{tabular}{|c|c|c|c|c|c|c|}
\hline & Rate & $\mathrm{n} / \mathrm{M}(\%)$ & $\begin{array}{l}\text { Unadjusted HR } \\
(95 \% \mathrm{CI})\end{array}$ & $P$-value & $\begin{array}{l}\text { Adjusted HR } \\
(95 \% \mathrm{CI})\end{array}$ & $P$-value \\
\hline Never & 19.2 & $142 / 1660(8.6)$ & - & & & \\
\hline$\leq 30 \mathrm{~min}$ twice/week & 18.3 & $174 / 2083(8.4)$ & $0.95(0.76-1.19)$ & 0.670 & $0.95(0.76-1.19)$ & 0.676 \\
\hline$>30 \mathrm{~min}$ twice/week & 12.3 & $246 / 4249(5.8)$ & $0.64(0.52-0.79)$ & $<0.001$ & $0.66(0.53-0.81)$ & $<0.001$ \\
\hline \multicolumn{7}{|l|}{ (a) Females } \\
\hline Never & 16.6 & 79/1044 (7.6) & - & & & \\
\hline$\leq 30 \mathrm{~min}$ twice/week & 16.8 & 91/1167 (7.8) & $1.01(0.75-1.36)$ & 0.960 & $1.05(0.77-1.43)$ & 0.751 \\
\hline$>30$ min twice/week & 11.4 & $115 / 2116(5.4)$ & $0.68(0.51-0.91)$ & 0.009 & $0.74(0.55-0.99)$ & 0.043 \\
\hline \multicolumn{7}{|l|}{ (b) Males } \\
\hline Never & 23.9 & 63/616 (10.2) & - & & & \\
\hline$\leq 30 \mathrm{~min}$ twice/week & 20.4 & $83 / 916(9.1)$ & $0.85(0.61-1.18)$ & 0.338 & $0.88(0.63-1.22)$ & 0.434 \\
\hline$>30 \mathrm{~min}$ twice/week & 13.2 & $131 / 2133(6.1)$ & $0.55(0.41-0.74)$ & $<0.001$ & $0.60(0.44-0.81)$ & 0.001 \\
\hline
\end{tabular}

CI, confidence interval; HR, hazard ratio; $\mathrm{n} / \mathrm{M}=$ number of patients with new-onset diabetes/number of patients in category. Rate is per 1000 years of patient follow-up. Patients with diabetes at baseline were excluded. The never-exercise group was designated an HR of 1. Adjusted HRs are adjusted for baseline age, gender, current smoking (yes/no), alcohol use (yes/no), race (white, black, other), degree of left ventricular hypertrophy and Framingham risk score.

result in best reduction in risk for cardiovascular events in our analysis can be assumed to be lower than recommended.

Several studies have evaluated the effect of PA in presumably healthy subjects $[4,7,10,15,24]$ or looked into intermediate end-points $[3,24,25,36-$ 38]. In contrast, the present analysis was conducted in older patients with significant cardiovascular pathology. Because of the severity of hypertension in this population, and the presence of LVH and other concurrent risk factors, major cardiovascular events occurred in the LIFE study at rates that were substantially higher than most studies that have examined the preventive impact of PA. Despite similar study drug dosages, heart rates and blood pressure control amongst the three PA categories in this analysis, patients in the highest PA level group (>30 min twice per week) experienced significantly lower rates of events compared with the lowest (never-exercise) and middle ( $\leq 30 \mathrm{~min}$ twice per week) groups. The level of PA in the three groups did not modify blood pressure or heart rate responses to intensive antihypertensive treatment. Moreover, there were no interactions between treatment and exercise. Thus, randomization to a beta-blocker did not cause a change in exercise level when compared with the losartan group.

Several studies looking into the effect of PA have been performed in men only $[4,6,7,9-11,13,16,27,31$, $33,35,39]$. Low physical fitness has been associated with higher levels of all-cause mortality in women [14]. In the present analyses, the protective effect of exercise was present both in men and women, both for cardiovascular end-points, all-cause mortality and new-onset diabetes. However, the differences were not statistically significant for all subgroups (stroke and myocardial infarction), most probably due to the lower number of subjects and thus statistical power in these sub-analyses. The absolute end-point rate per 1000 years of follow-up, however, was clearly higher amongst males than females.

Regular aerobic exercise reduces the risk of new-onset diabetes [36-38, 40, 41], and exercise training has been shown to improve insulin action and glucose tolerance in patients with impaired glucose tolerance and type 2 diabetes [37]. There are reduced risks for cardiovascular disease, cardiovascular death and all-cause death in men with type 2 diabetes who exercised [39]. In the present analyses, we also observed a similar pattern in a 
hypertensive high-risk population. The difference was still significant after adjustment for body mass index and other baseline variables.

There are some limitations to this analysis. In contrast to most studies looking into the effect of PA, the present analysis was based on self-reported activity level and not objectively measured fitness. We are unable to quantify the level (e.g. METS) or type of PA reported in this study. The ranges within the PA categories, especially the highest level, may be quite broad; however, we do not expect that this population of patients aged 55-80 years with hypertension and LVH would have exercised to an extent that would have significantly increased the median exercise level in the $>30 \mathrm{~min}$ twice a week group. Moreover, patients may have been self-sorted based on their underlying health and function so that higher exercise may not have been the cause of the observed benefits, but may have been a marker of better health. We are unable to assess whether unmeasured behavioural covariates may have contributed to our findings. A strength of our findings is that adjusting the analysis for baseline smoking status, alcohol consumption, gender, age, LVH and Framingham risk score did not influence the statistical significance for the primary composite end-point. Importantly, this was a large, well-conducted end-point trial that included careful adjudication of each reported end-point.

A modest level of self-reported PA ( $>30$ min twice per week) in patients with hypertension and LVH in the LIFE study was associated with significant reductions in risk for the primary composite endpoint and its components of cardiovascular death, stroke and myocardial infarction, and also all-cause mortality and new-onset diabetes.

\section{Conflict of interest statement}

Drs Dahlöf, Devereux, Julius, Kizer and Kjeldsen have received grant support from Merck \& Co., Inc., the sponsor of the LIFE study. Drs Dahlöf, Devereux, Julius and Kjeldsen are members of the LIFE Steering Committee. Dr Gleim, Mr Brady, and Ms Lyle and Hille are, or have been, Merck employees and may own stock or hold stock options in the company.

\section{References}

1 Pate RR, Pratt M, Blair SN et al. Physical activity and public health. A recommendation from the Centers for Disease Control and Prevention and the American College of Sports Medicine. JAMA 1995; 273: 402-7.

2 American Heart Association. Heart Disease and Stroke Statistics - 2005 Update. Dallas, TX: American Heart Association, 2005.

3 Thompson PD, Buchner D, Piña IL et al. Exercise and physical activity in the prevention and treatment of atherosclerotic cardiovascular disease: a statement from the Council on Clinical Cardiology (Subcommittee on Exercise, Rehabilitation, and Prevention) and the Council on Nutrition, Physical Activity, and Metabolism (Subcommittee on Physical Activity). Circulation 2003; 107: 3109-16.

4 Ekelund LG, Haskell WL, Johnson JL et al. Physical fitness as a predictor of cardiovascular mortality in asymptomatic North American men. The Lipid Research Clinics Mortality FollowUp Study. N Engl J Med 1988; 319: 1379-84.

5 Lee IM, Sesso HD, Oguma Y, Paffenbarger RS Jr. Relative intensity of physical activity and risk of coronary heart disease. Circulation 2003; 107: 1110-6.

6 Lee IM, Sesso HD, Paffenbarger RS Jr. Physical activity and coronary heart disease risk in men: does duration of exercise episodes predict risk? Circulation 2000; 102: 981-6.

7 Sandvik L, Erikssen J, Thaulow E, Erikssen G, Mundal R, Rodahl K. Physical fitness as a predictor of mortality among healthy, middle-aged Norwegian men. N Engl J Med 1993; 328: 533-7.

8 Lee CD, Folsom AR, Blair SN. Physical activity and stroke risk: a meta-analysis. Stroke 2003; 34: 2475-81.

9 Lee CD, Blair SN. Cardiorespiratory fitness and stroke mortality in men. Med Sci Sports Exerc 2002; 34: 592-5.

10 Myers J, Prakash M, Froelicher V, Do D, Partington S, Atwood JE. Exercise capacity and mortality among men referred for exercise testing. N Engl J Med 2002; 346: 793-801.

11 Paffenbarger RS Jr, Hyde RT, Wing AL, Lee IM, Jung DL, Kampert JB. The association of changes in physical-activity level and other lifestyle characteristics with mortality among men. N Engl J Med 1993; 328: 538-45.

12 Blair SN, Kampert JB, Kohl HW III et al. Influences of cardiorespiratory fitness and other precursors on cardiovascular disease and all-cause mortality in men and women. JAMA 1996; 276: 205-10.

13 Farrell SW, Kampert JB, Kohl HW III et al. Influences of cardiorespiratory fitness levels and other predictors on cardiovascular disease mortality in men. Med Sci Sports Exerc 1998; 30: 899-905.

14 Oguma Y, Sesso HD, Paffenbarger RS Jr, Lee IM. Physical activity and all cause mortality in women: a review of the evidence. Br J Sports Med 2002; 36: 162-72.

15 Blair SN, Kohl HW III, Paffenbarger RS Jr, Clark DG, Cooper $\mathrm{KH}$, Gibbons LW. Physical fitness and all-cause mortality. A prospective study of healthy men and women. JAMA 1989; 262: 2395-401. 
16 Blair SN, Kohl HW III, Barlow CE, Gibbons LW. Physical fitness and all-cause mortality in hypertensive men. Ann Med 1991; 23: 307-12.

17 Dahlöf B, Devereux R, de Faire U et al. The Losartan Intervention For Endpoint reduction (LIFE) in Hypertension Study: rationale, design, and methods. Am J Hypertens 1997; 10: 705-13.

18 Dahlöf B, Devereux RB, Julius S et al. Characteristics of 9194 patients with left ventricular hypertrophy. The LIFE study. Losartan Intervention For Endpoint reduction in hypertension. Hypertension 1998; 32: 989-97.

19 Dahlöf B, Devereux RB, Kjeldsen SE et al. Cardiovascular morbidity and mortality in the Losartan Intervention For Endpoint reduction in hypertension study (LIFE): a randomized trial against atenolol. Lancet 2002; 359: 995-1003.

20 WHO Study Group. Diabetes Mellitus (technical report series 727). Geneva: WHO, 1985.

21 Lindholm LH, Ibsen H, Borch-Johnsen $\mathrm{K}$ et al. Risk of newonset diabetes in the Losartan Intervention For Endpoint reduction in hypertension study. J Hypertens 2002; 20: 1879-86.

22 Anderson KM, Wilson PWF, Odell PM et al. An updated coronary risk profile. A statement for health professionals. Circulation 1991; 83: 356-62.

23 Pescatello LS, Franklin BA, Fagard R, Farquhar WB, Kelley GA, Ray CA. American College of Sports Medicine position stand. Exercise and hypertension. Med Sci Sports Exerc 2004; 36: $533-53$.

24 Blair SN, Goodyear NN, Gibbons LW, Cooper KH. Physical fitness and incidence of hypertension in healthy normotensive men and women. JAMA 1984; 252: 487-90.

25 Ishikawa-Takata $\mathrm{K}$, Ohta $\mathrm{T}$, Tanaka $\mathrm{H}$. How much exercise is required to reduce blood pressure in essential hypertensives: a dose-response study. Am J Hypertens 2003; 16: 629-33.

26 Manson JE, Hu FB, Rich-Edwards JW et al. A prospective study of walking compared with vigorous exercise in the prevention of coronary heart disease in women. $N$ Engl $\mathrm{J} \mathrm{Med}$ 1999; 341: 650-8.

27 Sesso HD, Paffenbarger RS Jr, Lee IM. Physical activity and coronary heart disease in men: the Harvard Alumni Health Study. Circulation 2000; 102: 975-80.

$28 \mathrm{Hu} \mathrm{G}$, Sarti C, Jousilahti P, Silventoinen K, Barengo NC, Tuomilehto J. Leisure time, occupational, and commuting physical activity and the risk of stroke. Stroke 2005; 36: 1994-9.

29 Lee IM, Paffenbarger RS Jr. Physical activity and stroke incidence: the Harvard Alumni Health Study. Stroke 1998; 29: 2049-54.

30 Rodriguez CJ, Sacco RL, Sciacca RR, Boden-Albala B, Homma S, Di Tullio MR. Physical activity attenuates the effect of increased left ventricular mass on the risk of ischemic stroke: the Northern Manhattan Stroke Study. J Am Coll Cardiol 2002; 39: $1482-8$

31 Lee IM, Hsieh CC, Paffenbarger RS Jr. Exercise intensity and longevity in men. The Harvard Alumni Health Study. JAMA 1995; 273: 1179-84.

32 Lee IM, Paffenarger RS Jr. Associations of light, moderate, and vigorous intensity physical activity with longevity. The Harvard Alumni Health Study. Am J Epidemiol 2000; 151: 293-9.

33 Church TS, Kampert JB, Gibbons LW, Barlow CE, Blair SN. Usefulness of cardiorespiratory fitness as a predictor of all-cause and cardiovascular disease mortality in men with systemic hypertension. Am J Cardiol 2001; 88: 651-6.

34 Crespo CJ, Palmieri MR, Perdomo RP et al. The relationship of physical activity and body weight with all-cause mortality: results from the Puerto Rico Heart Health Program. Ann Epidemiol 2002; 12: 543-52.

35 Blair SN, Kohl HW III, Barlow CE, Paffenbarger RS Jr, Gibbons LW, Macera CA. Changes in physical fitness and all-cause mortality. A prospective study of healthy and unhealthy men. JAMA 1995; 273: 1093-8.

36 Helmrich SP, Ragland DR, Leung RW, Paffenbarger RS Jr. Physical activity and reduced occurrence of non-insulin-dependent diabetes mellitus. $N$ Engl J Med 1991; 325: 147-52.

37 Ivy JL. Role of exercise training in the prevention and treatment of insulin resistance and non-insulin-dependent diabetes mellitus. Sports Med 1997; 24: 321-36.

38 Knowler WC, Barrett-Connor E, Fowler SE et al. Reduction in the incidence of type 2 diabetes with lifestyle intervention or metformin. N Engl J Med 2002; 346: 393-403.

39 Tanasescu M, Leitzmann MF, Rimm EB, Hu FB. Physical activity in relation to cardiovascular disease and total mortality among men with type 2 diabetes. Circulation 2003; 107: 2435-9.

40 Albright A, Franz M, Hornsby G et al. American College of Sports Medicine position stand. Exercise and type 2 diabetes. Med Sci Sports Exerc 2000; 32: 1345-60.

41 Tuomilehto J, Lindstrom J, Eriksson JG et al. Prevention of type 2 diabetes mellitus by changes in lifestyle among subjects with impaired glucose tolerance. $N$ Engl J Med 2001; 344: $1343-50$.

Correspondence: Eigil Fossum, Department of Cardiology, Ullevaal University Hospital, N-0407 Oslo, Norway. (fax: +4722119181; e-mail: eigil.fossum@medisin.uio.no). 